\title{
$\mathrm{SRC}$ 기둥-RC보 약축방향 접합부 상세의 구조성능에 대한 실험적 연구
}

\author{
문정호 $^{1)} \cdot$ 임재형 ${ }^{2)} \cdot$ 오경환 $^{3)} \cdot$ 김성호 ${ }^{4)} \cdot$ 이강민 $^{5 / *}$ \\ ${ }^{1)}$ 한남대학교 건축학부 ${ }^{2)}$ 우송정보대학 리모델링건축과 ${ }^{3)}$ 삼성물산(주) 건설부문 ${ }^{4}$ 건구조엔지니어링(주) ${ }^{5}$ 충남대학교 건축학부

\section{Cyclic Load Testing for Weak Axis Joints Connected with SRC Column and RC Beams}

\author{
Jeong-Ho Moon, ${ }^{1)}$ Jae-Hyung Lim, ${ }^{2)}$ Kyung-Hwan Oh, ${ }^{3)}$ Sung-Ho Kim, ${ }^{4)}$ and Kang-Min Lee)* \\ ${ }^{1)}$ Dept. of Architectural Engineering, Hannam University, Daejeon 306-791, Korea \\ ${ }^{2)}$ Dept. of Remodeling Architecture, Woosong Information College, Daejeon 300-715, Korea \\ ${ }^{3)}$ Samsung Corporation, Seoul 137-956, Korea \\ ${ }^{4)}$ Gun Structural Engineering, Co. Ltd., Seoul 133-834, Korea \\ ${ }^{5)}$ Dept. of Architectural Engineering, Chungnam National University, Daejeon 305-764, Korea
}

\begin{abstract}
An objective of this study is to evaluate the structural performance of the weak axis SRC column-RC beam joints by experiments. Although one of common joint types is the connection with standard hooks, it has been required to examine its safety and to settle problems of the joint among practical engineers. Specimen types are classified into two categories, namely the type of standard hook and the type of shape improvement. The first one is consisted of three specimens which are reference type, development length modification type, and development length supplement type. Three specimens for shape improvement were made with variations on the arrangement of longitudinal reinforcements and the development length. Test results based on cyclic loadings were discussed with load-deflection curves, maximum strengths, strength degradations beyond the maximum. It was found that the standard hook types showed premature failures and consequent strength degradations due to splitting of joint concrete. However, satisfactory performance was obtained with the shape improvement type with wing-plate welding. No premature failures and strength degradations were detected with the specimens.
\end{abstract}

Keywords : SRC column-RC beam joint, development length, standard hook, wing-plate welding

\section{1. 서 론}

역타공법 (top-down 공법)에서 SRC기둥과 $\mathrm{RC}$ 보를 사 용하는 경우 이질재료 사이의 접합부가 발생한다. SRC 기둥-RC보 접합부는 기둥의 관점에서 강축방향과 약축 방향 접합부로 나눌 수 있는데, 이들 접합부는 $\mathrm{RC}$ 보가 연속보로서 역할을 할 수 있도록 하는 접합 방법이다. 즉, $\mathrm{SRC}$ 기둥의 철골부재로 인하여 $\mathrm{RC}$ 보 인장철근이 연 속적으로 배근되지 못하고 절단되기 때문에, 적절한 방 법을 사용하여 $\mathrm{RC}$ 보 인장철근이 연속적으로 배근될 수 있도록 하는 접합 방법이다.

강축방향 접합부에 대한 종류 및 구조성능 평가와 약 축방향 접합부에 대한 구조성능 평가 ${ }^{1,2)}$ 는 기존연구에서 수행된 바 있다. 하지만 이들 기존연구에서 강축방향 접

*Corresponding author E-mail : leekm@cnu.ac.kr

Received August 1, 2008, Revised November 29, 2008,

Accepted January 28, 2009

(C) 2009 by Korea Concrete Institute
합부의 구조내력은 설계강도 이상의 내력을 확보하고 있 는 것으로 확인되었으나, 약축방향 접합부는 설계강도에 못 미치는 내력을 보유하고 있음이 확인되었다. 이는 시 공 상의 이유로 콘크리트구조설계기준 ${ }^{3}$ 의 인장철근 정 착길이가 확보되지 못한 상태로 보 주철근을 철골기둥의 웨브면에서 절곡하여 정착시키기 때문이다. 또한 최근 활 발히 진행되고 있는 복합구조에 대한 연구에서도 기둥과 보가 모두 $\mathrm{SRC}$ 구조이거나 $\mathrm{RC}$ 기둥에 철골 보 혹은 $\mathrm{SRC}$ 기둥에 철골 보를 접합하는 경우에 대한 연구는 많지만, $\mathrm{SRC}$ 기둥-RC보 접합부에 대한 연구가 극히 드문 실정이 다. 따라서 $\mathrm{SRC}$ 기둥-RC보 접합방식에 대한 구조성능의 검증 및 문제점에 대한 개선안의 제시가 시급한 실정이다. 따라서 본 연구에서는 국내 현장에서 사용하고 있는 $\mathrm{SRC}$ 기둥-RC보 접합부 약축방향 접합부에 대한 실험 연 구 수행을 통하여 구조성능을 평가하며, 향후 국내 $\mathrm{SRC}$ 기둥-RC보 약축방향 접합부의 표준상세를 제공하는 것 을 연구의 목적으로 한다. 


\section{2. 기존 연구}

국내 현장조사 및 설계도서 등의 자료조사를 통한 SRC 기둥-RC보 약축방향 접합방식은 Fig. 1과 같이 기둥면으 로부터 철골웨브까지의 공간에 표준갈고리를 갖는 인장 철근으로 정착시키는 약축방향 철근배근형이 주로 사용 되고 있다. 약축방향 철근배근형은 콘크리트구조설계기 준 $^{3)}$ 에 의한 인장철근의 정착길이가 확보되지 못한 경우 가 일반적이다.

$\mathrm{SRC}$ 기둥-RC보 약축방향 접합부의 구조성능 평가와 관 련한 국외 자료는 거의 없으며, 주영규 등른 약축방향 접합부에 대한 단조 및 반복가력 하에서의 구조성능에 대한 제한적인 실험 연구를 수행하였다. 그 결과, 국내 에서 사용하고 있는 약축방향에 대한 접합형식은 그 구 조내력이 설계내력을 상회하지 못하고 있음을 제시하였 다. 특히, 기둥 콘크리트가 떨어져 나오는 쪼개짐파괴 현 상이 나타나고 있음을 제시하였다.

이러한 제한적인 실험 연구 결과로부터 SRC기둥-RC 보 약축접합부의 구조성능과 관련한 일반적인 결론을 유 추하기는 매우 어려운 상황이며, 약축방향 접합부 상세 를 현장에서 사용하기 위해서는 충분한 설계내력을 보유 한 접합상세의 개발이 시급한 실정이다.

따라서, 본 연구에서는 기존 현장에서 사용하고 있는 접합상세 및 본 연구에서 제안하는 접합상세를 갖는 실 험체에 대한 실험 연구를 통하여 각 접합부의 구조성능 을 평가하였다.

\section{3. 실 함}

\section{1 실험체 계획 및 설계}

약축방향 접합부는 기존 연굴에서도 증명된 것처럼 $\mathrm{RC}$ 보에 배근된 주철근의 정착길이가 충분히 확보되지 않은 상태로 $\mathrm{SRC}$ 기둥에 정착되었기 때문에 기둥 콘크리 트가 떨어져 나오는 쪼개짐 파괴현상이 발생한다. 이는
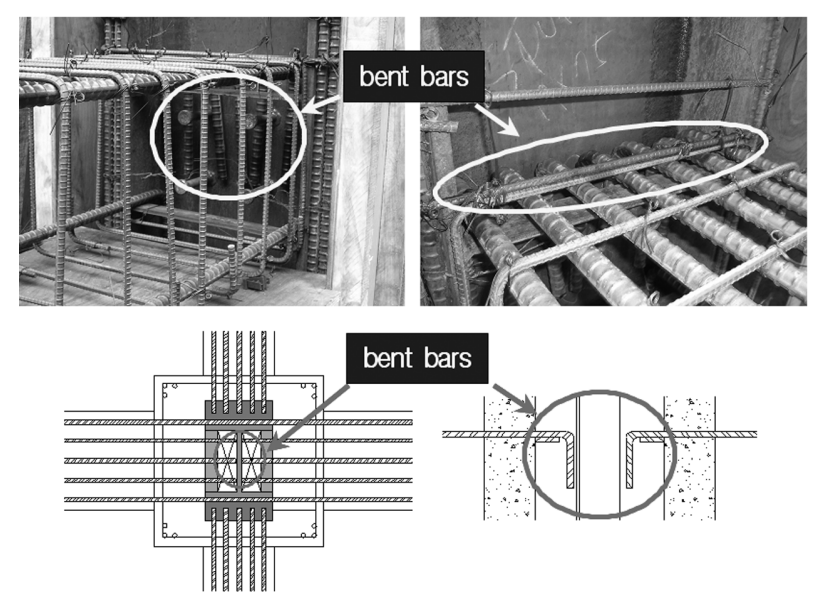

Fig. 1 Cross section detail
구조체가 발휘하여야 할 보유내력에 도달하지 못하고, 취 성파괴가 발생하는 주원인이 될 수 있다.

본 연구에서는 이를 해결할 수 있는 하나의 대안으로 콘크리트구조설계기준의 규정에 따라 $\mathrm{RC}$ 보 주철근의 정 착길이를 확보할 수 있도록 보정하는 설계를 하였다 또 한, 기존 연구레에서 비교적 우수한 성능을 보여주었던 강축방향 넓은 보 실험체와 유사한 접합부 형상을 갖는 약축방향 접합부 실험체를 계획하였다. 실험체는 표준갈 고리 상세 그룹과 접합부 형상 개선 그룹 등 두 가지의 그룹으로 구분하였으며 이를 Table 1에 정리하였다.

표준갈고리 상세 그룹의 실험체는 현재 현장에서 일반 적으로 사용되는 접합형상을 기준 실험체 (WRC-F0)로 하였다. $\mathrm{RC}$ 보 주철근의 부족한 정착길이를 보정하하기 위하여 주철근을 추가로 배근한 실험체 (WRC-D0)와 보 -기둥 접합부 콘크리트 구속을 위하여 쉬어코넥터와 전 단보강근을 사용한 실험체 (WRC-FH)로 구성되어 있다.

접합부 형상 개선 그룹 실험체는 세 가지의 상세를 사 용하였다. WRC-FP 실험체는 일부 철근은 $\mathrm{SRC}$ 기둥의 철 골에 용접된 연결철판에 용접하고, 나머지 철근은 SRC 기둥의 철골 웨브에 미리 설치한 구멍을 통하여 관통하 도록 배근한 실험체이다. 여기서 철골 기둥 웨브 구멍에 의한 단면 결손은 일본건축학회의 철골철근콘크리트 배 근지침헤에서 규정하고 있는 단면결손의 제한 범위 이내 가 되도록 하였다. WRC-FW 실험체의 일부 철근은 SRC 기둥 철골 웨브에 용접된 연결철판에 용접하고, 나머지 철근은 넓은 보를 이용하여 $\mathrm{SRC}$ 기둥의 철골 옆으로 통 과하도록 배근한 실험체이다. WRC-FA 실험체는 RC보 철근의 표준갈고리 정착길이를 확보하기 위하여 약축방 향으로 기둥 폭을 크게 확대한 실험체이다. 이상 6가지 접합 형상을 대상으로 가능한 실험 변수를 선정하였고, 실험체는 마산 $\mathrm{OO}$ 빌딩의 지하2층 보-기둥 접합부를 대 상으로 선정하였다.

Table 1 Specimen parameters

\begin{tabular}{|c|c|c|}
\hline Group & Name & Parameters \\
\hline \multirow{3}{*}{$\begin{array}{l}\text { Standard } \\
\text { hook type }\end{array}$} & WRC-F0 & $\begin{array}{l}\text { Do not meet the code requirement of } \\
\text { anchorage length (bent bars), frequently } \\
\text { used type in the field }\end{array}$ \\
\hline & WRC-D0 & $\begin{array}{l}\text { Meet the code requirement of anchor- } \\
\text { age length by adding the number of bars } \\
\text { (bent bars) }\end{array}$ \\
\hline & WRC-FH & $\begin{array}{l}\text { Do not meet the code requirement of } \\
\text { anchorage length (bent bars), frequently } \\
\text { used type in the field }+ \text { hoops in the } \\
\text { joints }\end{array}$ \\
\hline \multirow{3}{*}{$\begin{array}{l}\text { Proposed } \\
\text { detail type }\end{array}$} & WRC-FP & $\begin{array}{l}\text { Passing through the column web hole }+ \\
\text { welding on the wing plates }\end{array}$ \\
\hline & WRC-FW & $\begin{array}{l}\text { Passing through outside of the column } \\
+ \text { welding on the wing plates }\end{array}$ \\
\hline & WRC-FA & $\begin{array}{l}\text { Extended column size to meet the code } \\
\text { requirement of anchorage length }\end{array}$ \\
\hline
\end{tabular}


실험체는 $\mathrm{RC}$ 보의 인장철근이 연속 배근되었을 경우와 동일한 내력을 발휘하도록 콘크리트구조설계기준 ${ }^{3)}$ 에 따 라 설계하였다. 실험체 크기는 실험실 여건을 고려하여 $2 / 3$ 축소율을 적용하였으나, 인장철근의 지름은 실험체 의 크기 축소율에 준하지 아니하고, 정착길이 보정계수 에 영향을 적게 미치는 $\mathrm{D} 22$ 이상의 이형철근을 사용하 였다. 이는 콘크리트구조설계기준 해설에 따르면 D19 이 하의 이형철근과 이형철선의 경우, 정착길이를 $20 \%$ 까지 줄일 수 있고, 실제 현장에서도 주로 D22 이상의 철근 을 사용하고 있기 때문이다. 또한 실험체의 축소율에 따 라 철근의 직경을 줄이면 연구 결과를 실제 구조물에 적 용하여 활용하는데 많은 어려움이 예상되기 때문에 D22 철근을 사용하였다.

일반적으로 설계단계에서는 SD400 철근을 주로 사용하 는데, 이로 인하여 $\mathrm{RC}$ 보에 많은 수의 철근이 배근되며, $\mathrm{SRC}$ 기둥의 철골과 간섭이 커져 시공성이 저하된다. 이러 한 이유로 현장에서는 고강도 (SD500) 및 대구경 철근을 사용하여 철근의 개수를 감소시킨다. 실험체의 설계에서 도 현장의 조건과 유사하도록 SD500 철근을 사용하였다. 실험체의 내력은 기존 연구 ${ }^{1)}$ 에서 우수한 성능을 보여준 강축방향 넓은보 형상과 유사하도록 설계하였다. 이상과 같은 절차에 의해 설계된 실험체 상세는 Figs. 2 7과 같

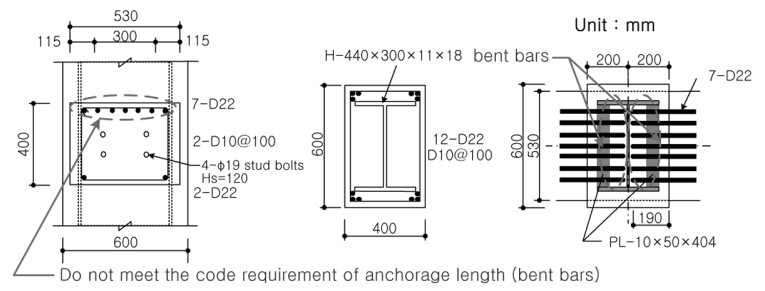

(a) Beam section (b) Column section (c) Connection detail

Fig. 2 Details for WRC-FO specimen

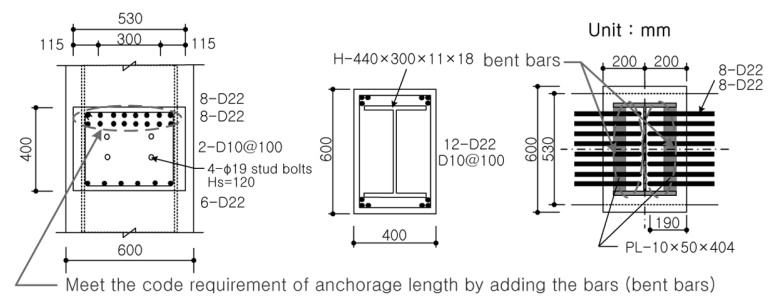

(a) Beam section (b) Column section (c) Connection detail

Fig. 3 Details for WRC-DO specimen

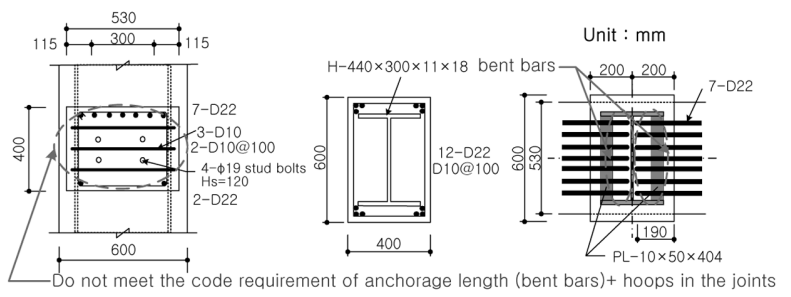

(a) Beam section (b) Column section (c) Connection detail

Fig. 4 Details for WRC-FH specimen

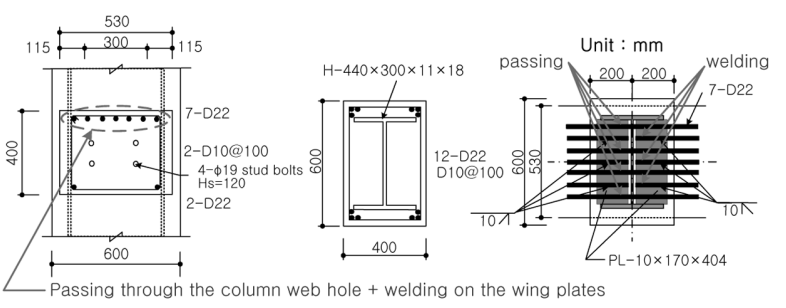

(a) Beam section (b) Column section (c) Connection detail

Fig. 5 Details for WRC-FP specimen

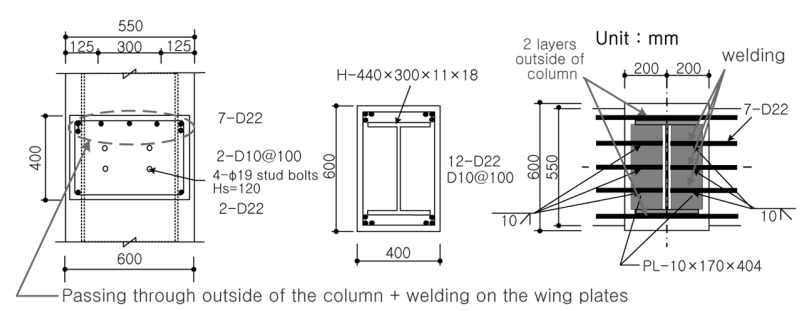

(a) Beam section (b) Column section (c) Connection detail

Fig. 6 Details for WRC-FW specimen

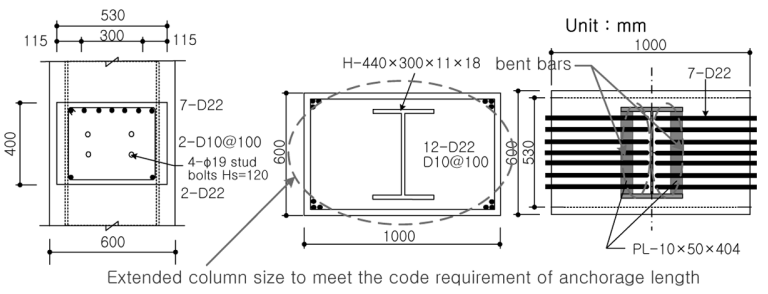

(a) Beam section (b) Column section (c) Connection detail

Fig. 7 Details for WRC-FA specimen

으며 실험체에 사용된 콘크리트, 철근 및 철골의 재료 시험 결과는 Table 2와 같다.

\section{2 측정 및 가력 계획}

실험을 진행하면서 $\mathrm{SRC}$ 기둥-RC보 접합부의 구조적 거 동, 즉 변위를 파악하기 위하여 Fig. 8과 같이 LVDT를 설치하였다. $\mathrm{RC}$ 보 철근이 $\mathrm{SRC}$ 기둥에 충분히 정착되어 보의 응력을 $\mathrm{SRC}$ 기둥에 전달할 수 있는지를 관찰하기 위하여 Fig. 9와 같이 보의 철근에 변형률게이지 (wire strain gage)를 부착하였다. 일반적으로 지하층 보-기둥 접 합부는 지진하중 등의 횡력에 의한 부모멘트가 발생하지

Table 2 Mechanical test results for Materials (MPa)

\begin{tabular}{c|c|c}
\hline Material & Design strength & Test results \\
\hline \hline \multirow{3}{*}{ Concrete } & \multirow{3}{*}{$30 \mathrm{MPa}$} & $\begin{array}{c}\mathrm{f}_{\mathrm{ck}}=29.8 \mathrm{MPa} \text { for WRC-F0, } \\
\text { WRC-D0, WRC-FH }\end{array}$ \\
\cline { 3 - 3 } & & $\begin{array}{r}\mathrm{f}_{\mathrm{ck}}=30.6 \mathrm{MPa} \text { for WRC-FP, } \\
\text { WRC-FW, WRC-FA }\end{array}$ \\
\hline Re-bars & $\mathrm{SD} 500$ & $\mathrm{~F}_{\mathrm{y}}=553.1 \mathrm{MPa}, \mathrm{F}_{\mathrm{u}}=699.3 \mathrm{MPa}$ \\
\hline Steel column & $\mathrm{SM} 490$ & $\mathrm{~F}_{\mathrm{y}}=407.9 \mathrm{MPa}, \mathrm{F}_{\mathrm{u}}=571.4 \mathrm{MPa}$ \\
\hline
\end{tabular}




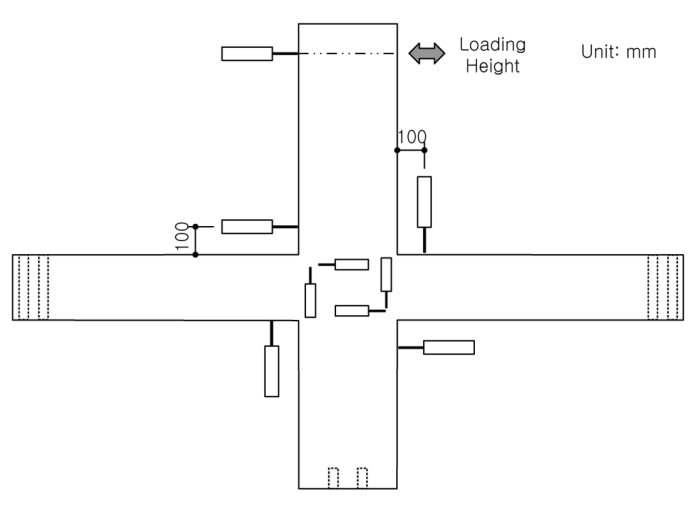

Fig. 8 LVDT layouts
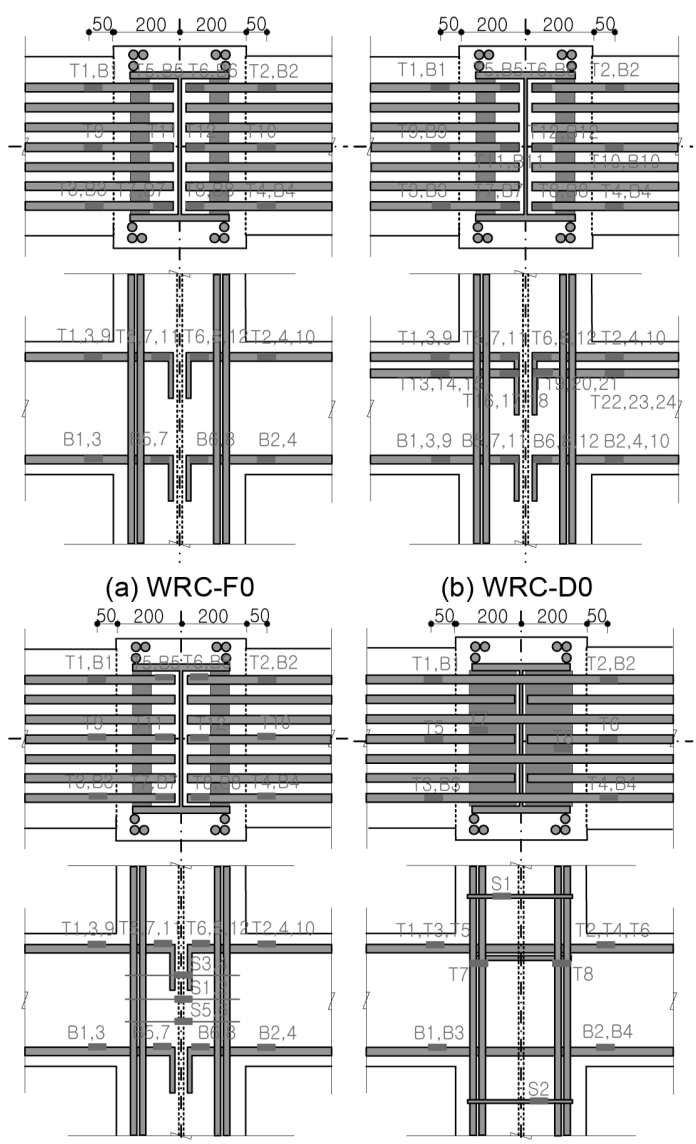

(c) WRC-FH

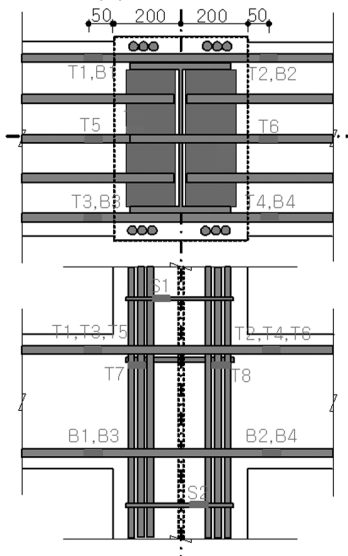

(e) WRC-FW

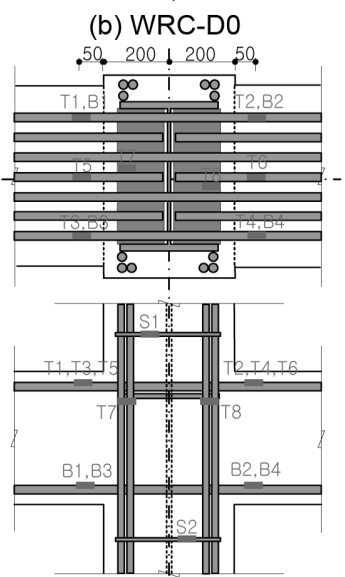

(d) WRC-FP

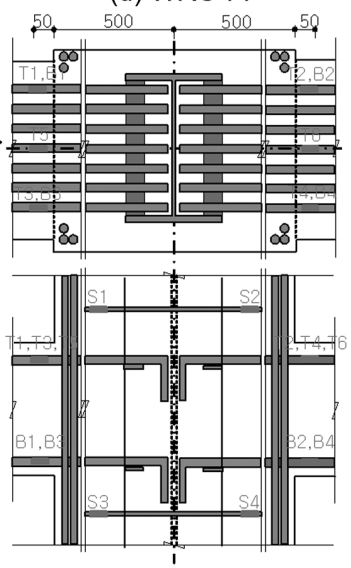

(f) WRC-FA

Fig. 9 Strain gage layouts

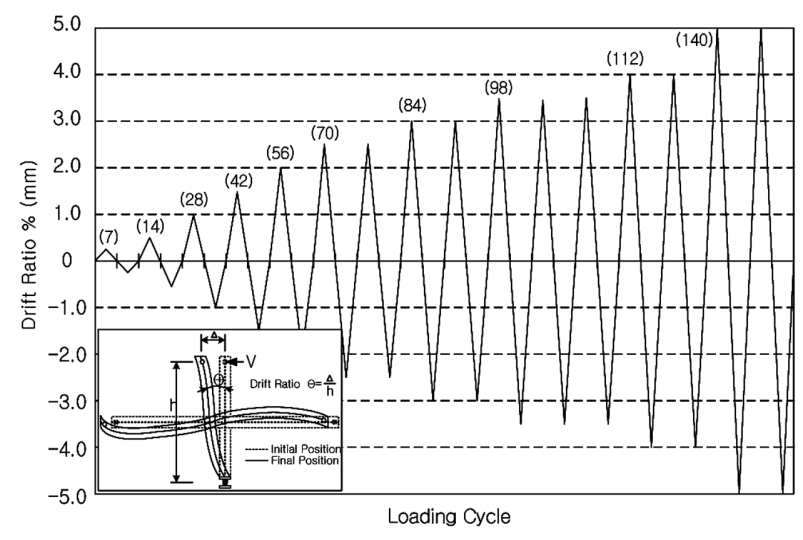

Fig. 10 Loading protocols

않지만, 건물이 초고층화 되면서 횡력에 의해 지하 1 층 등의 얕은 지하층의 경우 부모멘트가 발생할 가능성이 있어 본 연구에서는 Fig. 10 과 같이 반복 가력을 계획하 였다.

\section{3 실험체 설치}

실험체 설치 상황은 Fig. 11과 같다. 그림에서 보는 바 와 같이 기둥 상부에 $1,000 \mathrm{kN}$ 용량의 액추에이터를 설 치하여 Fig. 10 의 가력계획에 따라 가력하였으며, 가력점 변위에 의한 변위 제어 방식으로 실험을 진행하였다. 실 험은 실험체의 파괴, 액츄에이터 변위의 한계 또는 최대 내력 이후 최대 하중의 $75 \%$ 까지 하중이 감소하는 경우 에 종료하는 것으로 하였다. ${ }^{5)}$ 기둥에 작용하는 수직 압 축력은 기둥상부에 오일잭과 로드셀을 설치하고 강봉을 이용하여 축력 $0.1 f_{c k} A_{g}=720 \mathrm{kN}$ 을 실험 종료 시까지 유 지하였다.

\section{4. 실험 결과의 분석}

\section{1 하중-변위 곡선}

본 절에서는 실험 결과로부터의 하중-변위 이력 및 최 대내력 도달 이후의 내력저하 등에 대한 거동을 비교 분석하였다. 서로 다른 설계조건을 갖는 실험체를 비교 하기 위하여 실험 결과로부터의 하중 (층간전단력, $\mathrm{V}$ )은 각 실험체의 공칭모멘트 $\left(\mathrm{M}_{\mathrm{n}}\right)$ 를 모멘트팔 길이로 나누어

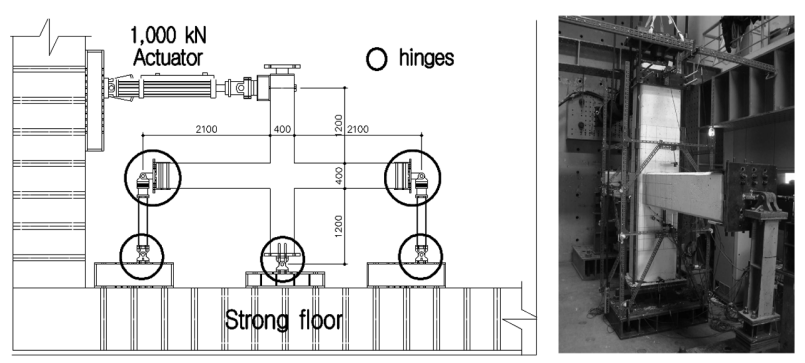

Fig. 11 Test set-up 


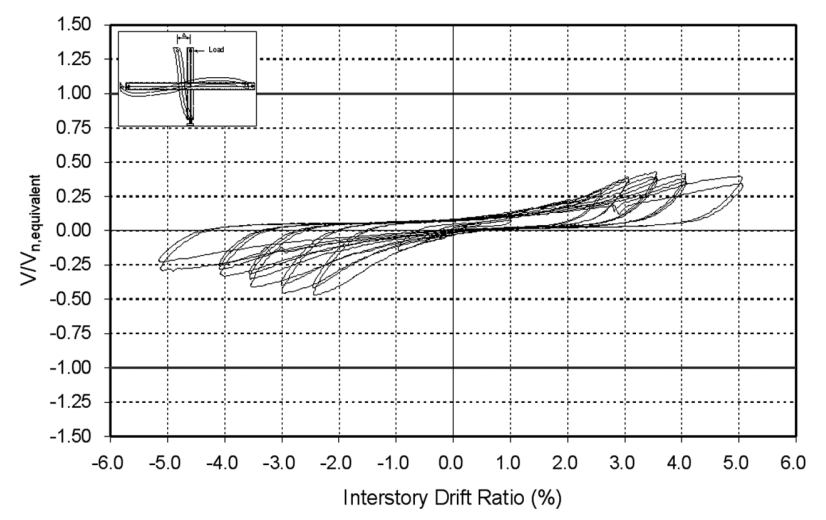

Fig. 12 Test result for WRC-FO

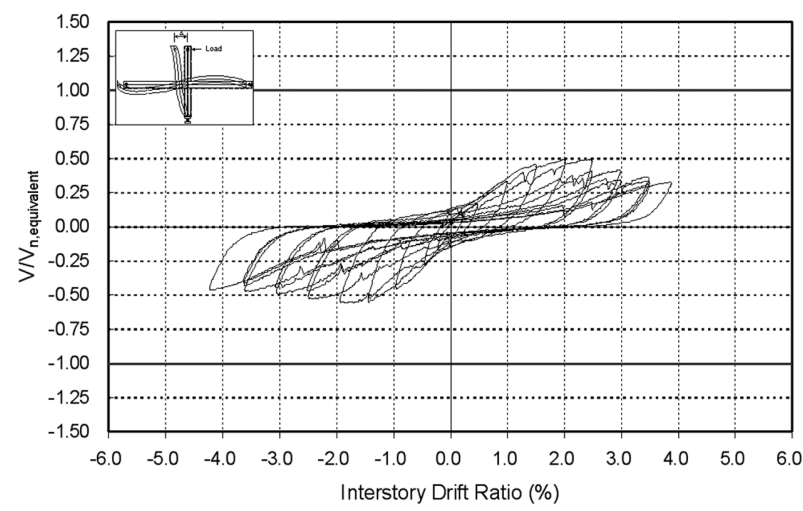

Fig. 13 Test result for WRC-D0

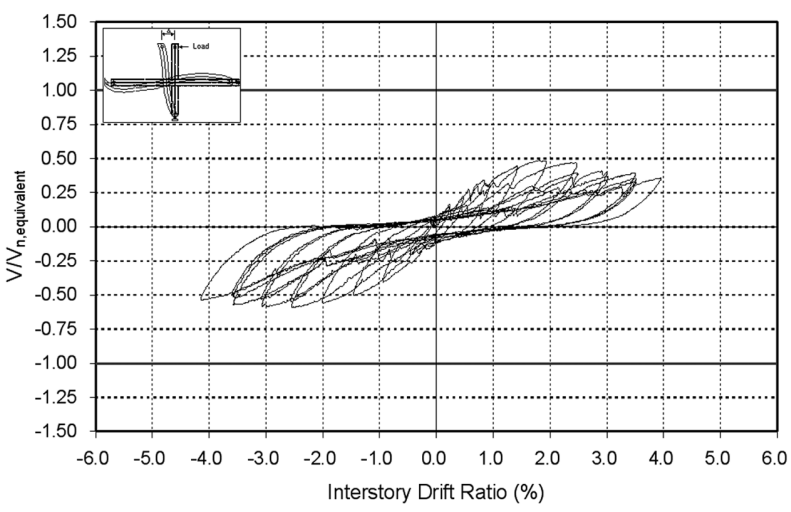

Fig. 14 Test result for WRC-FH

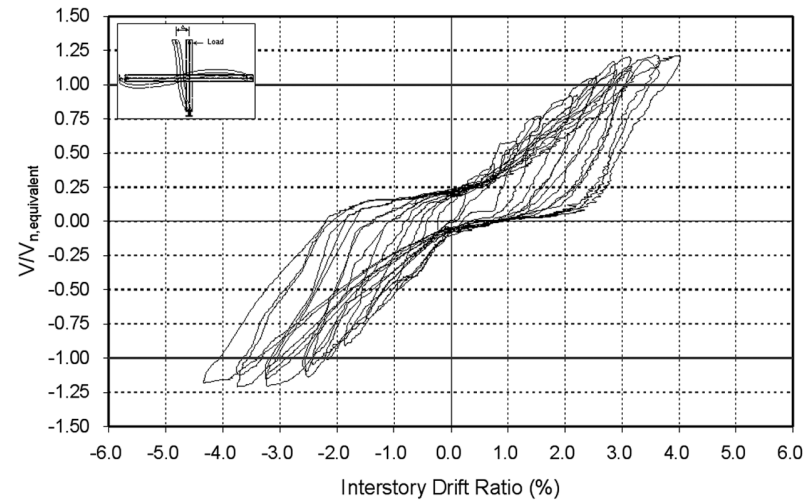

Fig. 15 Test result for WRC-FP
산정한 등가 공칭 층간전단력 $\left(\mathrm{V}_{\mathrm{n} \text {,equivalent }}\right)$ 으로 무차원화 하였으며, 변위는 층간변위률 $(\%)$ 로 무차원화하였다. 각 실험체의 무차원화된 하중-변위 곡선은 Figs. 12 17과 같 으며, 그림에서 상 - 하 굵은 수평선은 실험체의 층간전 단력 $(\mathrm{V})$ 과 등가 공칭 층간전단력의 비가 1.0 인 선을 나 타낸다

반복하중 하에서의 실험체의 이력 거동을 비교하기 위 하여 이들 실험체의 각 사이클별 최대점을 연결한 무차 원화된 하중-변위 곡선을 Fig. 18에 나타내었다. 또한, 각 실험체의 내력을 평가하기 위하여 Fig. 19에는 실험체들 의 등가 층간전단력 $(\mathrm{V})$ 을 등가 공칭 층간전단력으로 무

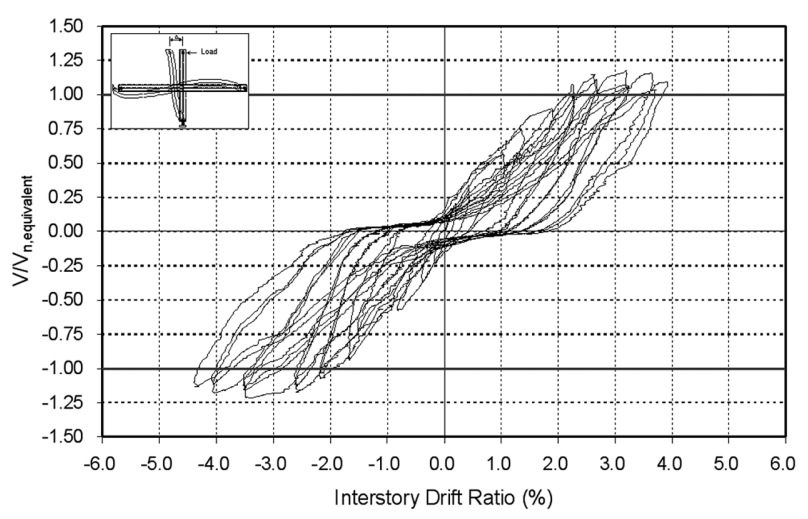

Fig. 16 Test result for WRC-FW

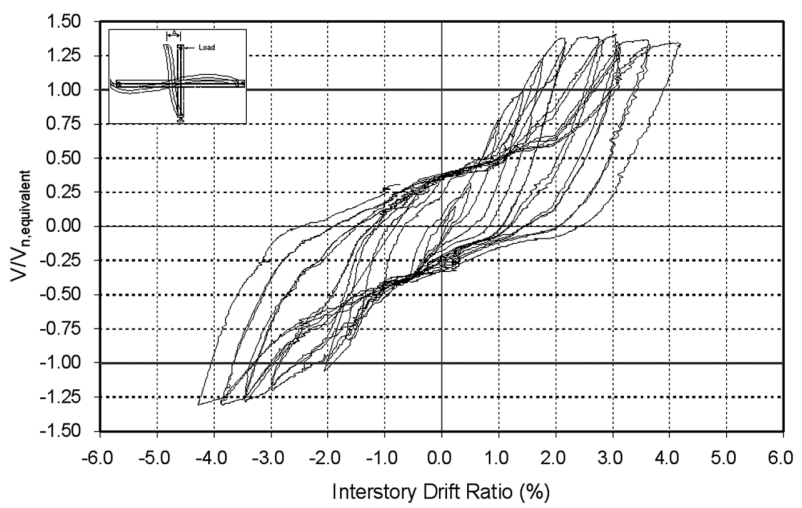

Fig. 17 Test result for WRC-FA

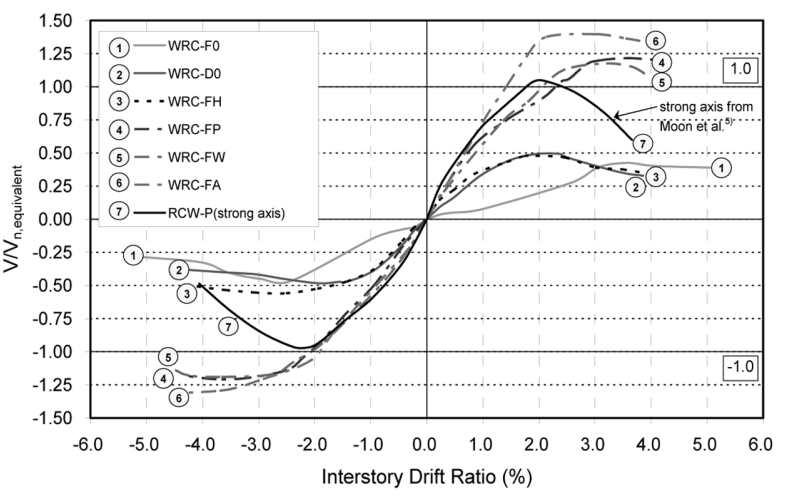

Fig. $18 \mathrm{~V} / \mathrm{N}_{\mathrm{n} \text {,equivalent }}$-drift ratio specimens 


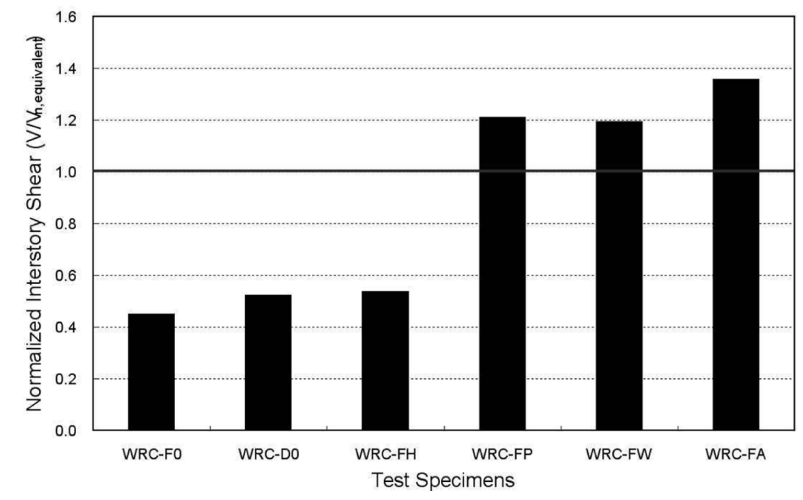

Fig. 19 Comparison of maximum strengths

차원화시킨 최대 내력을 비교하여 나타내었다.

그림에서 보는 바와 같이, 표준갈고리 상세그룹의 실 험체들 (WRC-F0, WRC-D0, WRC-FH)은 전반적으로 거 의 유사한 이력 거동을 보여주었다. 이들 실험체들의 최 대 층간전단력은 설계내력인 공칭 등가 층간전단력의 약 $50 \%$ 수준인 것으로 나타났다. 이는 철근콘크리트 보의 주철근 정착길이를 콘크리트구조설계기준 ${ }^{3}$ 에서 제시하고 있는 수준으로 확보하기 위하여 $\mathrm{SRC}$ 기둥 철골 부분의 웨브쪽으로 철근을 구부려 넣은 접합상세가 보로부터 기 둥면으로 전달되는 모멘트를 충분히 전달할 수 없었기 때문에 나타난 결과로 사료된다.

특히, 일반적으로 현장에서 자주 사용되고 있는 접합 상세를 갖고 있는 WRC-F0 실험체의 정착길이 부족을 보완하기 위하여 보 주철근의 양을 늘려 정착길이를 줄 임으로서 기준에서 제시하고 있는 정착길이를 만족시킬 수 있도록 설계된 WRC-D0 실험체나, 기존 연굴에서 보고된 바와 같이 철골 기둥면 내로 구부린 보의 주철 근이 기둥면 내의 콘크리트를 물고 떨어지는 쪼개짐 파 괴 현상 (Fig. 20 참조)을 보완하기 위하여 접합부 부분 에 띠근으로 보완한 실험체인 WRC-FH 실험체는 모두 공칭 등가 층간전단력에 훨씬 못 미치는 수준 (약 $50 \%$ 정도)의 최대 층간전단력을 보여주었다. 이는 WRC-D0 나 WRC-FH와 같은 보완 방법으로는 약축방향 접합부 에서 구부려 넣은 보의 주철근에 의한 기둥면 내의 콘 크리트를 물고 떨어지는 쪼개짐 파괴 현상을 해결할 수 없음을 의미한다.

한편, 보 철근의 정착길이를 확보하기 위하여 접합부 형상을 개선한 실험체들 (WRC-FP, WRC-FW, WRC-FA) 의 구조성능은 표준갈고리 상세그룹의 실험체들에 비해 우수한 것으로 나타났다. 또한 Fig. 18에서와 같이 문정 호 등이이 연구한 강축방향 접합부를 갖는 실험체들과 유 사하거나, 보다 우수한 구조 성능을 보유하고 있음도 알 수 있다. 이는 개선된 접합 형상을 갖는 약축방향 접합 부 실험체의 접합상세는 $\mathrm{RC}$ 보 주철근이 $\mathrm{SRC}$ 기둥에 충 분하게 정착되고 있음을 의미한다. 그리고 표준갈고리 상 세그룹 실험체의 접합상세에서와 같이 기둥면 콘크리트 를 물고 떨어지는 쪼개짐 파괴 현상이 효율적으로 방지
되고 있는 것으로 나타났다. 이는 Figs. 20과 21의 실험 체 파괴상황 사진에서도 확인할 수 있다.

\section{2 연성능력 및 강성 평가}

본 절에서는 실험체의 연성능력을 평가하기 위하여 연 성지수 $(\mu)$ 를 사용하였다. 연성지수 $(\mu)$ 는 실험체의 파괴, 즉 각 실험체가 최대 내력의 $75 \%$ 까지 내력이 저하되었 을 때의 구조물의 최대변위 $\left(\delta_{\max }\right)$ 를 Park method ${ }^{6}$ 에 의 한 항복변위 $\left(\delta_{\mathrm{y}}\right)$ 로 나누어서 구하였고, 이를 비교한 도 표를 Fig. 22에 나타내었다.

그림에서 보는 바와 같이 전체적으로 실험체들 간의 연성능력의 차이가 크게 나타나지 않았지만, 표준갈고리

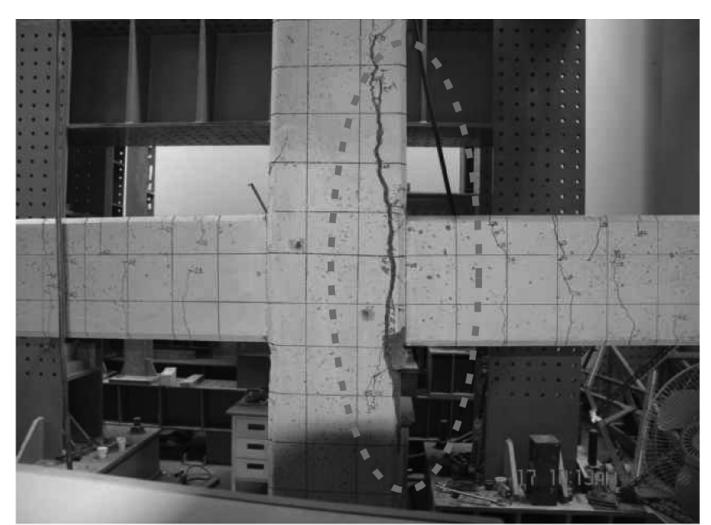

(a) WRC-FO

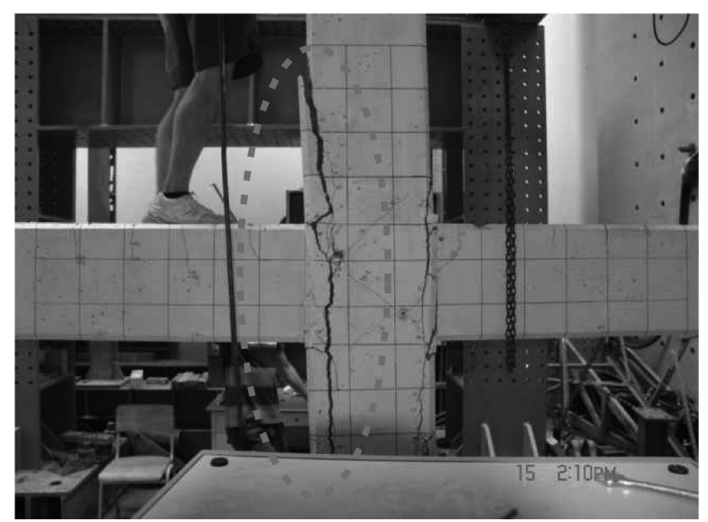

(b) WRC-D0

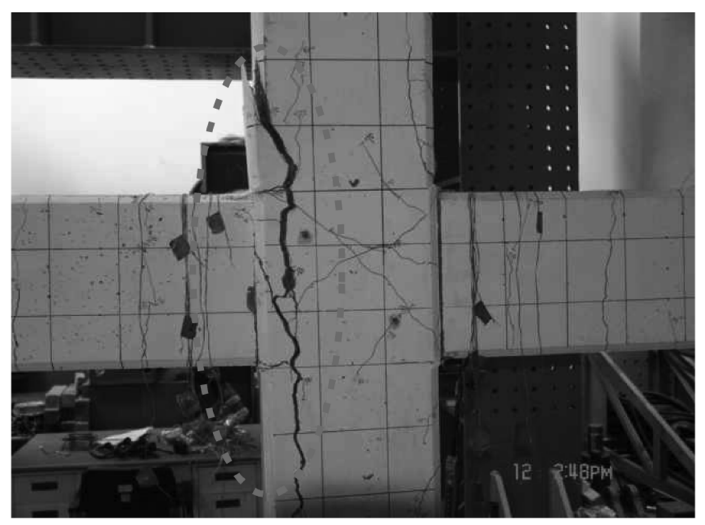

(c) WRC-FH

Fig. 20 Fractured shapes of standard hook type specimens 


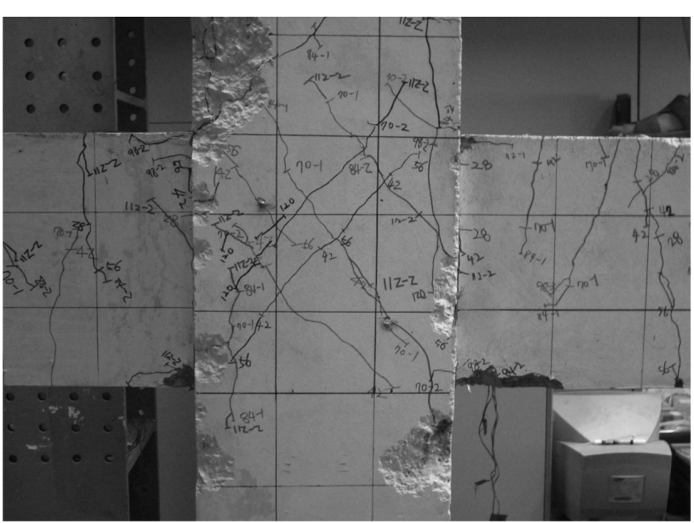

(a) WRC-FP

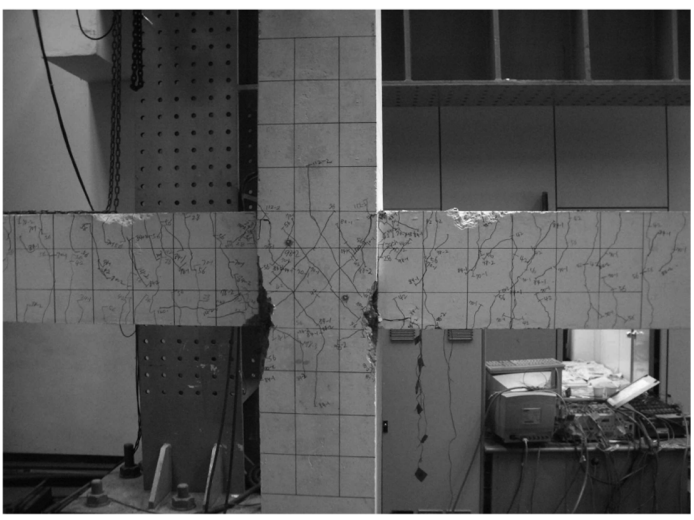

(b) WRC-FW

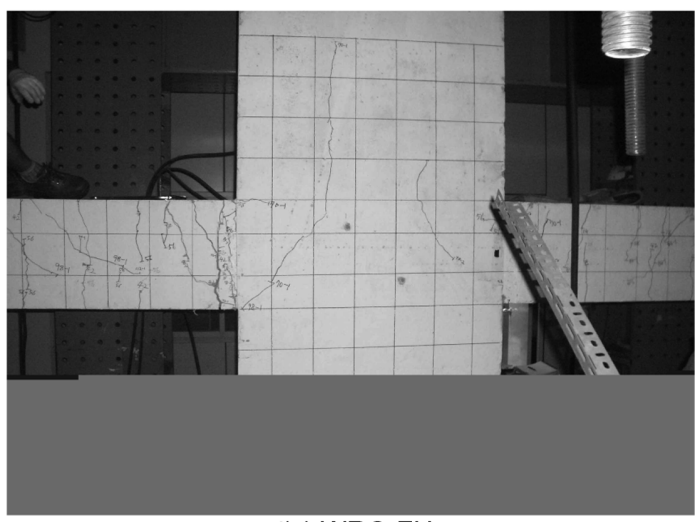

(c) WRC-FH

Fig. 21 Fractured shapes of proposed detail type specimens

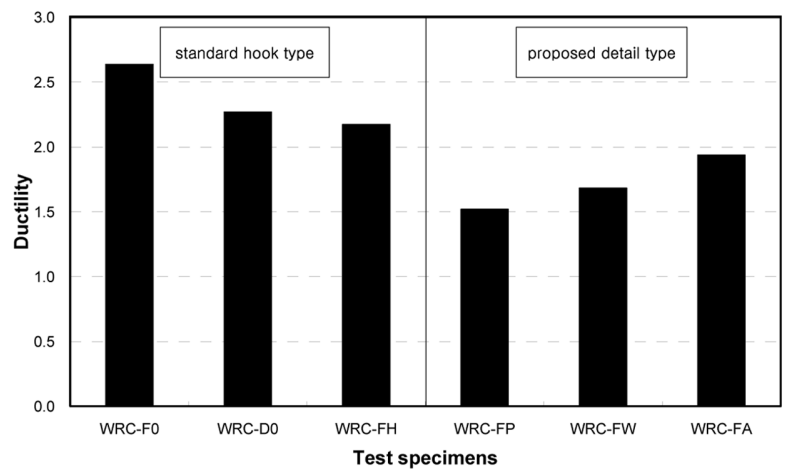

Fig. 22 Comparison of ductilities

상세그룹의 실험체들이 개선된 접합부 형상을 갖도록 제 안된 상세그룹 실험체들에 비해 다소 우수한 연성능력을
보여주고 있다. 이는 Fig. 23에 도식적으로 나타낸 바와 같이 상대적으로 실험 결과로부터의 항복 변위 $\delta_{\mathrm{y} 1}$ 은 주 철근이 항복하였을 때를 가정한 항복 변위 $\delta_{\mathrm{y} 2}$ 에 비해 작으며, 실험 결과로 부터의 최대 변위 $\delta_{\max 1}$ 은 주 철근 이 항복하였을 때를 가정한 최대 변위 $\delta_{\max 2}$ 에 비해 크 기 때문에 나타난 결과로 사료된다.

Fig. 24에는 실험체들 간의 강성을 비교하였는데, 그림 에서 보는 바와 같이 개선된 접합부 형상을 갖도록 제 안된 상세그룹 실험체들이 표준갈고리 상세그룹의 실험 체들에 비해 우수한 강성을 보여주고 있다. 또한, 표준 갈고리 상세그룹의 실험체 중, 보강이 전혀 이루어지지 않은 기준실험체인 WRC-F0 실험체에 비해 RC보 주철 근의 정착길이를 보정하여 부족한 정착길이 만큼 배근되 어야할 주철근을 추가로 배근한 WRC-D0 실험체와 보기둥 접합부 콘크리트의 구속을 위한 쉬어코넥터의 배치 및 접합부 콘크리트를 구속하기 위한 전단보강근을 사용 한 WRC-FH 실험체의 강성이 우수한 것으로 나타났다.

\subsection{RC보 주철근의 변형률 비교}

Figs. 25와 26에는 실험체별로 모멘트에 대한 임계단면 에서의 $\mathrm{RC}$ 보 주철근의 변형률을 나타내었다.

그림에서 보는 바와 같이 표준갈고리 상세그룹의 실험 체들 (WRC-F0, WRC-D0, WRC-FH)의 RC보 주철근 변

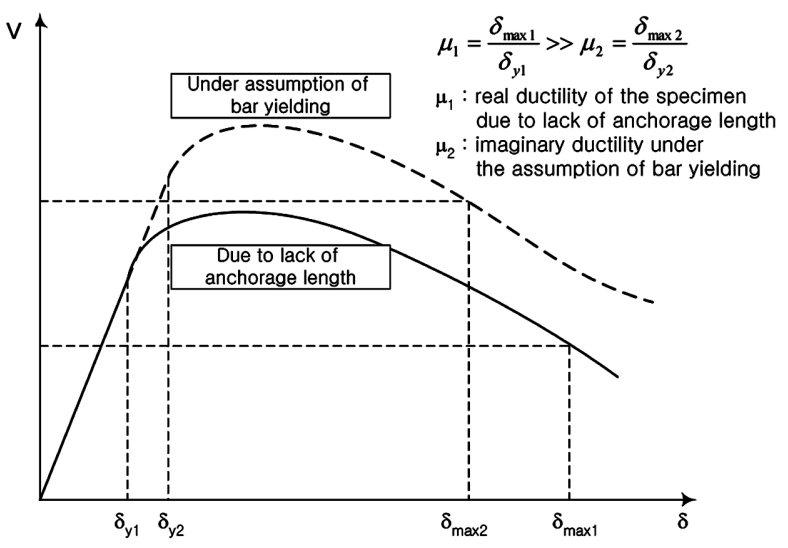

Fig. 23 Conceptual ductility capacity of specimens

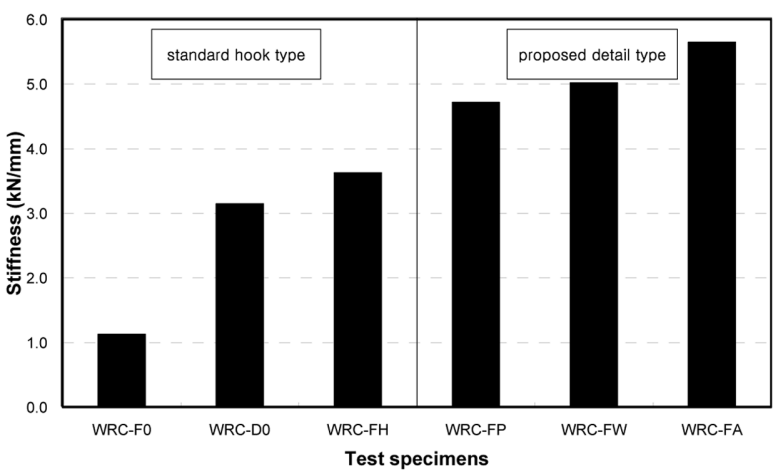

Fig. 24 Comparison of stiffness 


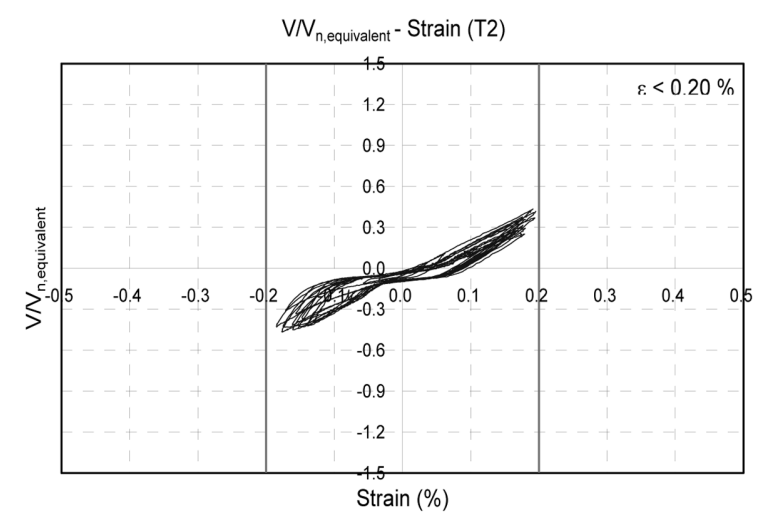

(a) WRC-FO

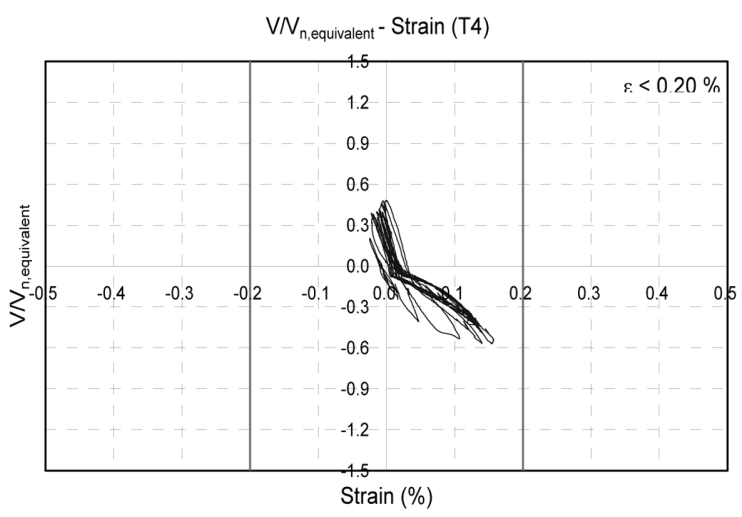

(b) WRC-D0

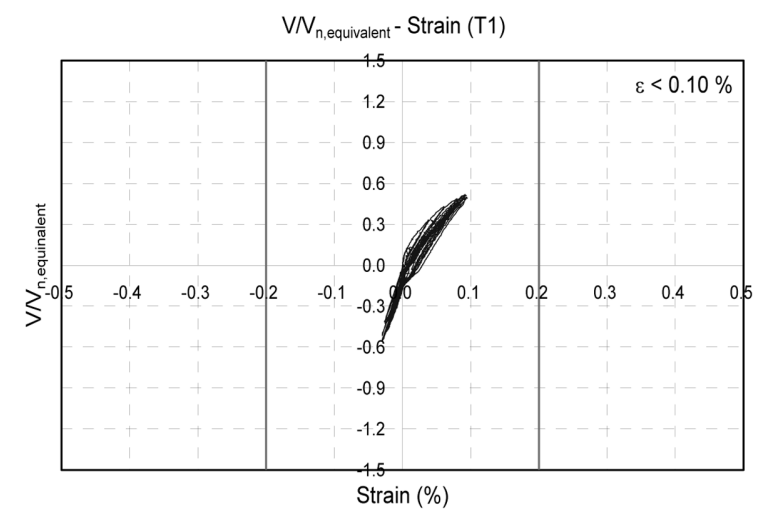

(c) WRC-FH

Fig. $25 \mathrm{~V} / \mathrm{N}_{\mathrm{n} \text {,equivalent }}$-strain (\%) curves for standard hook type

형률이 $0.2 \%$ 미만으로 항복변형률에 미치지 못한 상태 에서 최대내력에 도달한 반면, $\mathrm{RC}$ 보 주철근의 정착길이 를 확보하기 위해 개선한 접합부 형상을 갖도록 제안된 상세그룹 실험체들 (WRC-FP, WRC-FW, WRC-FA)의 $\mathrm{RC}$ 보 주철근 변형률은 모두 $0.2 \%$ 이상으로 항복변형률 을 상회하였을 때 최대내력에 도달하고 있었다.

이는 전술한 바와 같이 표준갈고리 상세그룹의 실험체 들은 $\mathrm{RC}$ 보 주철근이 충분한 정착길이를 확보하지 못한 상태로 $\mathrm{SRC}$ 기둥에 정착되었기 때문에 $\mathrm{RC}$ 보의 주철근이 기둥면 내의 콘크리트를 물고 떨어지는 쪼개짐 파괴가 발생하였고, 또한 보로부터 기둥면으로 전달되는 모멘트 를 충분히 전달하지 못하고 있었기 때문이다. 반면, 개 선된 접합부 형상을 갖도록 제안된 상세그룹 실험체들에

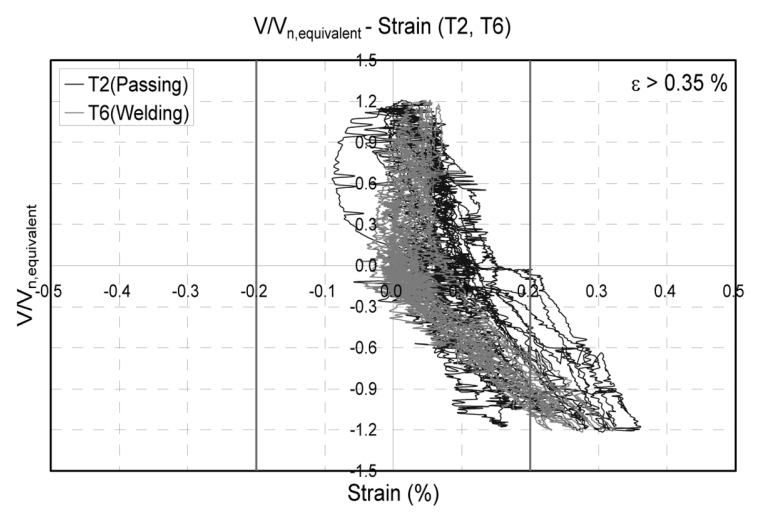

(a) WRC-FP

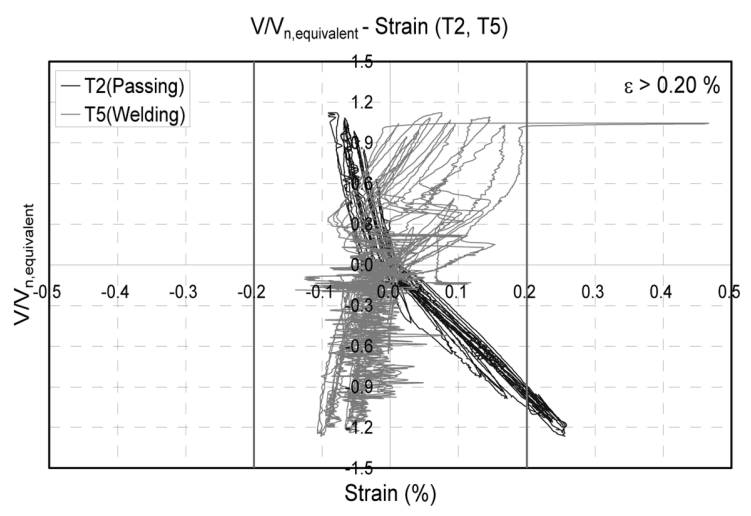

(b) WRC-FW

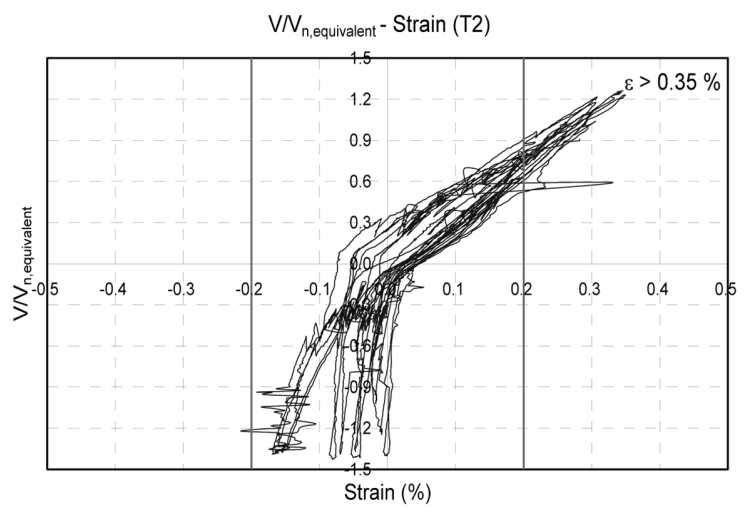

(c) WRC-FA

Fig. $26 \mathrm{~V} / \mathrm{N}_{\mathrm{n} \text {,equivalent }}$-strain (\%) curves for proposed detail type

서는 $\mathrm{RC}$ 보 주철근이 기둥에 충분히 정착되고 있었기 때 문에 나타난 결과라고 판단된다.

\section{5. 결 론}

$\mathrm{SRC}$ 기둥-RC보 약축방향 접합부 실험체에 대한 실험 결과로부터 다음과 같은 결론을 유추하였다.

1) 표준갈고리 상세그룹의 실험체들 (WRC-F0, WRC$\mathrm{D} 0, \mathrm{WRC}-\mathrm{FH}$ )은 모두 제안 상세그룹 실험체들 (WRCFP, WRC-FW, WRC-FA)에 비해 매우 열악한 구조 적 성능을 갖고 있음이 확인되었다. 이는 $\mathrm{RC}$ 보의 주철근이 기둥면 내 콘크리트를 물고 떨어지는 쪼 개짐 파괴 현상, 즉 주철근의 정착길이 부족 때문 
에 나타난 결과로 판단된다.

2) $\mathrm{RC}$ 보 주철근의 정착길이 확보를 위하여 기존연구 의 강축방향 접합부 형상을 응용하여 개선한 약축 방향 접합부 실험체들 (WRC-FP, WRC-FW, WRC$\mathrm{FA})$ 은 강축방향 넓은 보 접합부 형상을 갖는 실험 체와 동일하거나 보다 우수한 구조적 성능을 보유 하고 있음을 확인하였다.

3) 약축방향 접합부 상세 중에서 $\mathrm{RC}$ 보의 일부 철근은 $\mathrm{SRC}$ 기둥 철골의 측면으로 통과시키고 나머지는 연 결철판에 용접한 $\mathrm{WRC}-\mathrm{FW}$ 실험체와 일부 철근은 $\mathrm{SRC}$ 기둥 철골의 웨브에 미리 설치에 놓은 구멍으 로 관통시키고 나머지 철근은 연결철판에 용접한 $\mathrm{WRC}-\mathrm{FP}$ 실험체는 그 구조성능이 모두 요구 구조 성능 이상인 것으로 확인되었기 때문에 실제 현장 에 적용할 수 있다고 사료된다.

4) $\mathrm{RC}$ 보 주철근의 정착길이 확보를 위하여 $\mathrm{SRC}$ 기둥 단면 크기를 약축방향으로 증가시킨 WRC-FA 실험 체의 경우, 그 구조성능은 매우 우수한 것으로 나 타났다. 그러나 $\mathrm{RC}$ 보의 주철근 정착길이의 확보를 위해서 기둥 크기가 비정상적으로 커져야 할 우려 가 있기 때문에 실제 현장에 적용하기에는 다소 무 리가 따를 것으로 사료된다.

\section{감사의 글}

이 논문은 2007년도 한남대학교 학술연구조성비 지원 에 의하여 연구되었다.

\section{참고문헌}

1. 문정호, 이강민, 임재형, 오경환, 김성호, "SRC기둥-RC보 강축접합부 상세의 구조성능 평가,” 콘크리트학회 논문 집, 19권, 4호, 2007, pp. 401 409.

2. 주영규, 천성철, “지하 구조물의 철골철근콘크리트 기둥 과 철근콘크리트 보 접합부의 구조 성능 평가," 대한건 축학회 논문집, 19권, 2호, 2003,pp. 17 24.

3. 한국콘크리트학회, 콘크리트 구조설계기준, 한국콘크리 트학회, 2003, 405 pp.

4. 日本建築學會, 鐵骨鐵筋コンワリ一ト造配筋指針・同解說, 日本建築學會, 1996, $461 \mathrm{pp}$.

5. Hawkins, N. and Ghosh, S. K., "Proposed Revisions to 1997 NEHRP Recommended Provisions for Seismic Regulations for Precast Concrete Structures Part 2-Seismic Force Resisting Systems," PCI Journal, Vol. 45, No. 5, 2000, pp. 34 45.

6. Park, R., "Ductility Evaluation from Laboratory and Analytical Testing State of the Art Report," Proceedings of Ninth Word Conference on Earthquake Engineering, Vol. VII, Tokyo-Kyoto, Japan, Aug. 1988, pp. 605 616.

요 약 본 연구는 $\mathrm{SRC}$ 기둥-RC보 약축방향 접합부에 대한 구조성능 평가 실험 연구이다. 현재 국내현장에서 많이 사용하고 있는 약축방향 접합방식은 구조성능이 명확하게 규명되지 않은 방식이 많으며, 이에 대한 안전성 확보 여부 의 검증 및 문제점에 대한 개선도 시급하다. 따라서 본 연구에서는 표준갈고리형 실험체 3 개와 접합부 형상 개선 실험 체 3 개 등 총 6 개의 실험체를 제작하였다. 표준갈고리형 실험체들은 기준실험체, 정착길이 보정 실험체, 쉬어코넥터 및 전단보강근에 의한 보강 실험체 등으로 구성되어 있다. 접합부 형상 개선 실험체들은 주철근배치 방식과 용접 그리고 정착길이 확보 실험체 등이다. 반복가력에 의한 실험을 통하여 하중-변위 곡선, 최대강도, 강도저감 등을 평가하였다. 실 험결과, 표준갈고리형 실험체들은 $\mathrm{RC}$ 보의 주철근이 기둥면 내 콘크리트를 물고 떨어지는 쪼개짐 파괴현상을 나타내었 으며, 구조성능도 불량하였다. 그러나 새로운 접합부 형상 개선 실험체들은 표준갈고리형 실험체들과 같이 기둥면 내 콘크리트를 물고 떨어지는 쪼개짐 파괴현상도 나타나지 않았으며, 구조성능도 양호하였다.

핵심용어 :SRC기둥-RC보 접합부, 정착길이, 표준갈교리, 연결철판 